\title{
ED-255EK Embeded Education Platform Sebagai Modul Praktikum Embeded System Dengan Robot Arm Module Dan Voice Module
}

\author{
I Nyoman Edy Saputra ${ }^{1}$, I Gusti agung Pt Raka Agung ${ }^{2}$, Yoga Divayana ${ }^{3}$ \\ [Submission: 18-10-2019, Accepted: 01-04-2019]
}

\begin{abstract}
Literally embedded systems are defined as equipment that computes a particular job. Embedded Linux System was also developed as a means of education, one of which is ED255EK Embedded Education Platform, designed to be very practical and consume very low power. ED-255EK is also equipped with a PXA255 processor that is compatible with ARM version 5TE ISA, so it can be used to carry out various kinds of lab work or experiments on embedded systems. The working principle of this tool begins with the configuration of data communication between Fedora Linux and ED-255EK. When the communication goes well, the ED-255EK system is downloaded to a laptop or computer that has been installed with the Fedora 9.0 Linux operating system. To take advantage of the ED255FPGA module, driver module installation is required first, after which the application program is installed. Laptops or computers that have installed the Fedora 9.0 Linux operating system will act as input and output programs making it easier to monitor each module that is being run. In the ARM robot module application program executed using the "./robot_app" command, the ARM 1923 robot module will move. The voice module 4321 application program is executed by pressing the Reset button, the Recog button, and the Traning button alternately, the module will record the sound given.
\end{abstract}

Keyword - ED-255EK, embedded system, linux fedora.

Intisari- Secara harfiah embedded system didefinisikan sebagai peralatan yang melakukan komputasi pada suatu pekerjaan khusus. Embedded Linux System juga dikembangkan sebagai sarana education, salah satunya yaitu ED-255EK Embedded Education Platfrom, didesain sangat praktis dan mengkonsumsi daya yang sangat rendah. ED-255EK dilengkapi juga dengan prosesor PXA255 yang kompatibel dengan ARM versi 5TE ISA, sehingga dapat digunakan untuk melakukan berbagai macam praktikum atau percobaan tentang embedded system. Prinsi kerja dari alat ini diawali dengan konfigurasi komunikasi data antara Linux Fedora dengan ED-255EK. Ketika komunikasi berjalan dengan baik, dilakukan pengunduhan dengan sistem ED-255EK ke laptop atau komputer yang telah dipasangi dengan sistem operasi Linux Fedora 9.0. Untuk memanfaatkan modul ED-255FPGA diperlukan pemasangan driver modul terlebih dahulu, setelah itu dilakukan pemasangan program aplikasi. Laptop atau komputer yang telah dipasang sistem operasi Linux Fedora 9.0 akan berperan sebagai input dan output program sehingga memudahkan untuk memonitoring setiap modul yang

${ }^{I}$ Mahasiswa Program Studi Teknik Elektro, Jalan Gunung Batur Gang Salak III No. 39 Denpasar Barat INDONESIA (tlp: 082341625446/087772203330;e-mail: saputra_edy14@yahoo.com)

2, 3 Program Studi Teknik Elektro Fakultas Teknik Universitas Udayana, Jln. Jalan Kampus Bukit Jimbaran 80361 INDONESIA (telp: 0361-703315; fax:0361-4321; e-mail: puturaka@ee.unud.ac.id, yogadivayana@gmail.com)

I Nyoman Edy Saputra: ED-255EK Embedded Education(...)
Pada program aplikasi modul robot ARM dieksekusi dengan menggunakan perintah “./robot_app”, maka modul robot ARM 1923 akan bergerak. Pada program aplikasi modul voice 4321 dieksekusi dengan menekan tombol Reset, tombol Recog, dan tombol Traning secara bergantian, maka modul akan merekam suara yang diberikan.

Kata kunci- ED-255EK, embedded system, linux fedora.

\section{PENDAHULUAN}

Secara harfiah embeddded system didefinisikan sebagai peralatan yang melakukan komputasi pada suatu pekerjaan khusus. Tidak seperti komputer yang dapat melakukan berbagai jenis pekerjaan, embedded system merupakan bagian dari system yang lain yang lebih besar, sehingga sistem ini tidak dapat berdiri sendiri[1]. Selain itu, embedded system dapat bekerja sendiri tanpa bantuan operator, walaupun banyak peralatan yang menggunakan embedded system dengan bantuan operator, sebagai contoh telepon genggam dan televisi.

Pada Penelitian sebelumnya telah dibuat pembelajaran embedded system berbasis Arduino mega 2560 dan MIT App Inventor. Penelitian ini memuat tentang proses pembelajaran mata kuliah Embedded System dengan pendekatan praktis berbasis arduino mega di Prodi Teknik Informatika ITATS. Materi pembelajaran meliputi akses digital I/O dan analog I/O melalui android mobile phone[2]. Penelitian selanjutnya dilakukan penerapan-penerapan modul embedded system Arduino untuk sistem pembelajaran prinsip kerja display LCD touch screen 3,2 inch pada aplikasi data curved ploting. Menggunakan perangkat keras embedded system arduino, dan display LCD touch screen Ulcd-32PTU-AR buatan 4D[3]. Penelitian lainnya membuat prototipe modul pembelajaran embedded system berbasis arduino. Prototipe embedded system ini dirancang secara terintegrasi, tiap-tiap modulnya dalam satu kesatuan papan PCB (Printed Circuit Board)[4].

Penelitian kali ini menggunakan ED-255EK yang menggunakan sistem operasi Linux Fedora yang dimana tidak ada lisensi untuk penggunaannya dan didukung CPU Intel XScale yang kompatibel dengan ARM versi 5TE ISA, mengadopsi super-pipeline RISC.

\section{KAJIAN PUSTAKA}

\section{A. Embedded System}

Berbeda pada komputer pada umunya yang digunakan untuk multifungsi, embedded system merupakan komputer yang didesain untuk melakukan beberapa fungsi khusus. Embedded System memiliki ciri-ciri diantaranya intruksi 
program (firmware) disimpan didalam ROM, prosesor yang digunakan berkategori mikroprosesor dan mikrokontroler yang dilengkapi peripheral chip.

\section{B. Sistem Operasi Linux}

Linux yang diperkenalkan pada tahun 1991 oleh Linus Torvalds merupakan sistem operasi yang berbasis UNIX salah satu contoh hasil pengembangan perangkat lunak bebas (Freeware) dan sumber terbuka (Open Source). Seiring dengan perkembangan teknologi, Linux juga mengalami perkembangan dimana banyak distro Linux yang dikembangkan. Linux Fedora merupakan salah satu distro Linux berbasis RPM dan yum yang dikembangkan oleh komunitas Fedora Project yang didukung oleh komunitas pemrograman serta disponsori oleh Red Hat. Linux Fedora memiliki kelebihan dimana tampilan desktop yang memukau sehingga popular di Amerika, tidak mudah terkena virus karena ada fitur keamanan SElinus, ditro yang banyak fiture, mapan dan aman. Kekurangan dari Linux Fedora adalah tidak sestabil Debian atau Slacware, tidak mudah dan semutakhir Suse atau Madrake untuk penggunakan desktop, multimedia yang kurang. Pada penelitian ini menggunakan Linux Fedora karena Linux Fedora memiliki karnel yang sesuai dengan karnel yang dibutuhkan pada ED255EK Embedded Education Platfrom. Linux Fedora yang digunakan memiliki versi Linux Fedora 9.0.

\section{ED-255EK}

ED-255EK merupakan papan sirkuit yang telah ditanam prosesor Intel XScale PXA255. Untuk konfigurasi ED-255EK menggunakana ethernet port dan serial port. ED-255EK Embedded Education Platfrom ditunjukkan pada Gambar 1

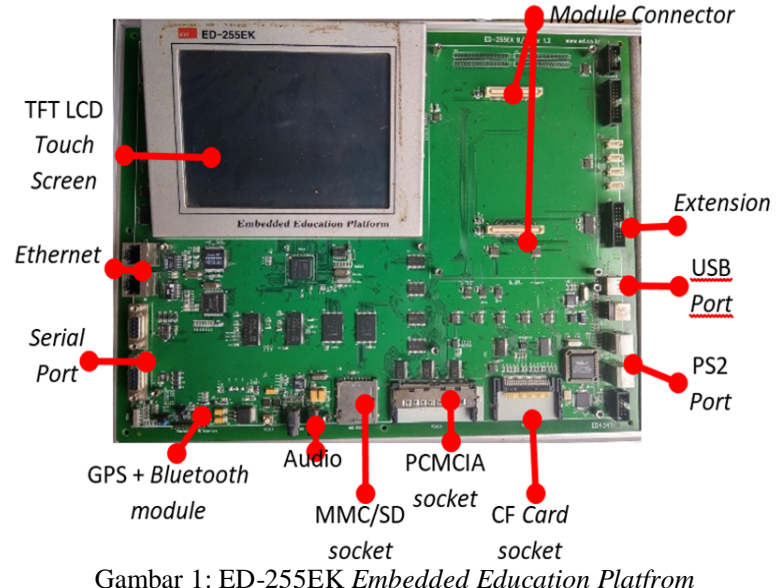

D. Intel XScale PXA255

XScale merupakan mikroarsitektur untuk central processing unit (cpu) yang dirancang oleh Intel dengan menggunakan arsitektur ARM. Arsitektur XScale didasarkan pada ARM versi 5TE ISA tanpa instruksi floating point, menggunakan tujuh stage interger dan delapan stage memory super-pipelined microarchitecture. Gambar 2 menunjukkan blok diagram dari Intel SXcale PXA255.

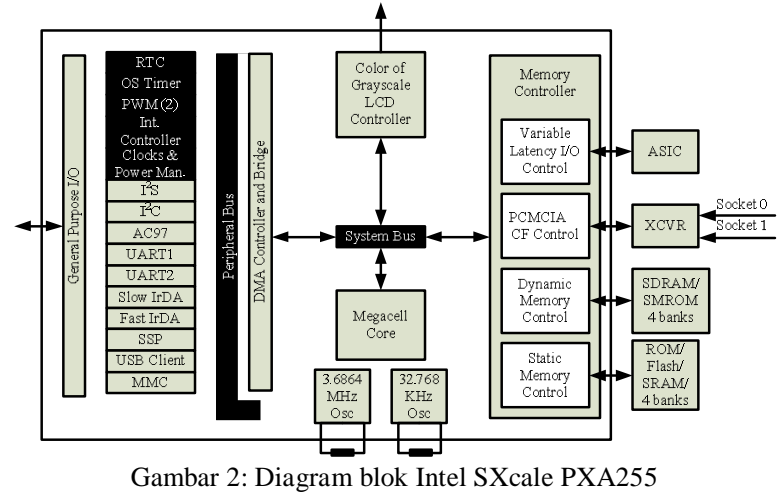

E. Modul Robot ARM 1923

Modul robot ARM disusun oleh rangkaian motor servo. Motor servo adalah sebuah motor DC dengan sistem umpan balik yang tertutup, dimana posisi rotornya akan diinformasikan kembali ke rangkaian kontrol yang ada di dalam motor servo. Motor sevo dipilih sebagai pengerak pada lengan robot karena memiliki torsi atau tenaga yang besar. Modul Robot ARM 1923 ditunjukkan pada Gambar 3.

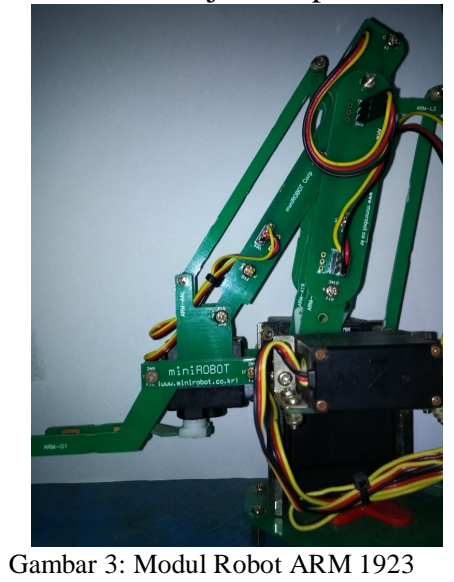

F. Voice Module 4321

Voice modul merupakan modul perekam suara yang terdiri dari beberapa komponen penting, diantaranya modul JT1000, power section, LED, push botoom dan expansion connector. Dimana untuk memasukan input suara digunakan MIC connector sedangkan untuk mengeluarkan output suara digunakan SPK connector. Voice modul ditunjukkan pada Gambar 4

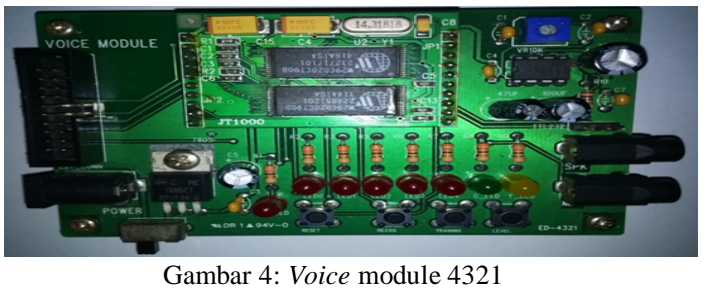

\section{METODE PENELITIAN}

ED-255EK sebagai modul praktikum embedded system dimulai dengan melakukan konfigurasi sistem operasi Linux Fedora 9.0 pada laptop atau komputer dengan menambahkan package Linux, pengaturan jaringan dan komunikasi data secara serial. Jika konfigurasi sistem operasi telah berhasil, dilanjutkan dengan pengaturan IP-Address dan pengunduhan 
file sistem ke dalam ED-255EK. Pengkonfigurasian ED255EK dilakukan dengan menghubungkan ED-255EK ke laptop atau komputer dengan menggunakan kabel ethernet dan kabel converter serial to USB. Konfigurasi pemasangan modul-modul pada ED-255EK ditunjukkan pada Gambar 5
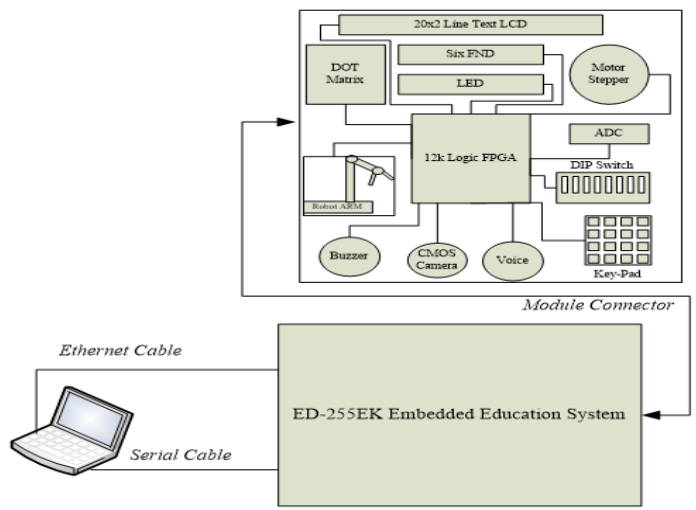

Gambar 5: Konfigurasi pemasangan modul-modul ED-255EK

Konfigurasi perangkat lunak (software) untuk modulmodul aplikasi pada penelitian ini menggunakan terminal Linux. Perancangan software meliputi pembuatan file driver dan program aplikasi pada modul lengan robot ARM 1923 dan modul voice 4321. Diagram alir untuk konfigurasi Software pada aplikasi modul robot ARM 1923 dan modul voice 4321 ditunjukkan pada Gambar 6.

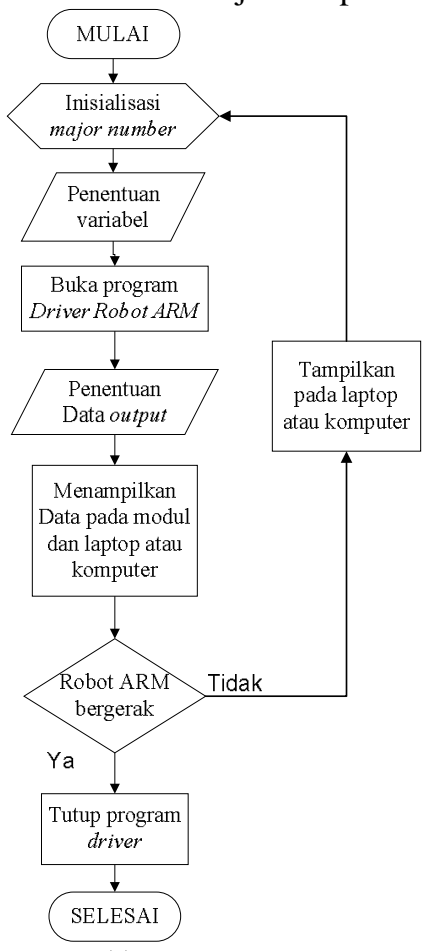

(a)

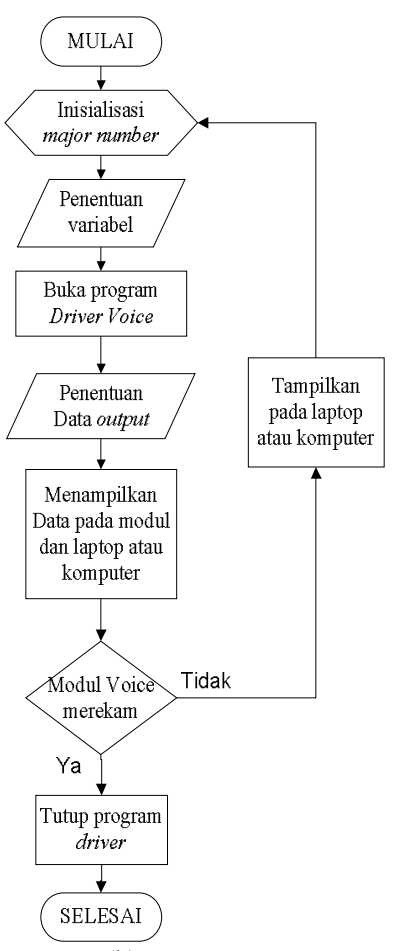

(b)
Gambar 6: Diagram alir konfigurasi Software pada aplikasi modul robot ARM 1923 (a) dan modul voice 4321 (b)

\section{IV.HASIL DAN PEMBAHASAN}

\section{A. Konfigurasi Sistem Linux Fedora}

Konfigurasi pada sistem operasi Linux Fedora dengan penambahan package Linux, diantaranya "tftp", "tftp-server", "karnel devel", dan "gcc". Penambahan package Linux dilakukan dengan memasukan perintah "yum install". Langkah I Nyoman Edy Saputra: ED-255EK Embedded Education(...) selanjutnya yaitu membuat direktori dengan nama tftpboot menggunakan perintah "nano /etc/xinetd.d/tftp". Dilanjutkan dengan pengeksekusian TFTP Demon dengan menggunakan perintah "/etc/init.d/xineted restart". Konfigurasi dilanjutkan dengan melakukan pengaturan pada NFS Server yang filenya dapat disalin dari CD ED-255EK dengan menggunakan perintah "cp" dan mengektraknya dengan perintah "tar-xzvf". Pada file export dilakukan pengaturan dengan menambahkan perintah “/etc/ED255_NFS_ROOT/192.168.1.211(rw,no_root _squash,no_all)". Langkah selanjutnya adalah melakukan restart pada NFS Server dengan menggunakan perintah "/etc/init.d/nfs restart" dan men-disabled Firewall dan SELinux. Langkah terakhir adalah dengan mengatur serial komunikasi antara ED-255EK dengan laptop menggunakan perintah "minicom-s".

\section{B. Konfigurasi ED-255EK}

Konfigurasi ED-255EK meliputi pengaturan IP Address dan pengunduhan file sistem ED-255EK. Pengaturan IP Address dilakukan dengan cara masuk pada file sistem ED255EK menggunakan perintah "minikom-s". Perintah yang dimasukan adalah "editenv" untuk mengatur IP Address pada alamat 192.168.1.211. Langkah selanjutnya adalah pengunduhan file sistem ED-255EK dengan menggunakan perintah "tftpboot a2000000 zImage.nfs", maka file sistem akan tersimpan pada alamat a2000000. Untuk melakukan booting dari alamat a2000000 digunakan perintah "bootm a2000000". Hasil pengunduhan dan booting dapat ditunjukkan pada Gambar 7.

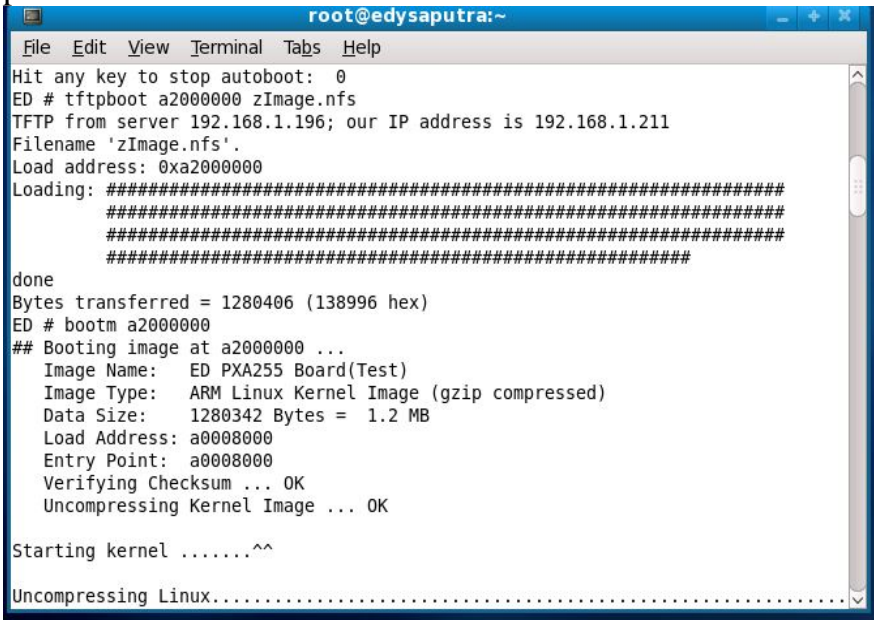

Gambar 7: Pengunduhan dan booting sistem ED-255EK

\section{Modul Robot ARM 1923}

Dalam pengendalian modul robot ARM 1923 dilakukan konfigurasi terhadap modul aplikasi dengan membuat direktori untuk penyimpanan file driver modul robot ARM 1923. Pembuatan direktori menggunakan perintah "mkdir-p /opt/ED255_NFS_ROOT/work/Robot_ARM/driver". File driver dan program aplikasi modul robot ARM 1923 akan dicrosscompiling menjadi format file "robot.o" dengan menggunakan perintah "make". File driver dan program aplikasi dengan format "robot.o" disalin ke ED-255EK dengan menggunakan perintah "insmod robot.o". Pada program aplikasi modul robot ARM dieksekusi dengan menggunakan perintah “./robot_app”, maka modul robot ARM 1923 akan bergerak yang ditunjukkan pada Tabel 1. p-ISSN:1693 - 2951; e-ISSN: 2503-2372 
TABEL 1

DATA HASIL PERGERAKAN MODUL ROBOT ARM 1923

\begin{tabular}{|c|c|c|}
\hline No & Gambar & Keterangan \\
\hline 1 & & $\begin{array}{l}\text { Saat program robot ARM pertama } \\
\text { kali dijalankan, maka penjepit dari } \\
\text { modul robot ARM akan terbuka }\end{array}$ \\
\hline 2 & & $\begin{array}{l}\text { Program kedua dijalankan maka } \\
\text { penjepit robot ARM akan menutup } \\
\text { kembali }\end{array}$ \\
\hline 3 & & $\begin{array}{l}\text { Program ketiga dijalankan maka } \\
\text { lengan robot akan bergerak ke } \\
\text { bawah }\end{array}$ \\
\hline 4 & & $\begin{array}{l}\text { Program keempat dijalankan maka } \\
\text { lengan robot ARM akan bergerak } \\
\text { ke depan }\end{array}$ \\
\hline 5 & & $\begin{array}{l}\text { Program kelima dijalankan maka } \\
\text { lengan robot ARM akan bergerak } \\
\text { kembali pada posisi sebelum } \\
\text { program keempat dijalankan }\end{array}$ \\
\hline 6 & & $\begin{array}{l}\text { Program keenam lengan robot } \\
\text { ARM akan bergerak ke atas }\end{array}$ \\
\hline 7 & & $\begin{array}{l}\text { Program ketujuh lengan robot } \\
\text { ARM akan berputar ke arah kiri }\end{array}$ \\
\hline 8 & & $\begin{array}{l}\text { Program kedelapan lengan robot } \\
\text { ARM akan kembali keposisi } \\
\text { semula }\end{array}$ \\
\hline
\end{tabular}

D. Modul Voice 4321

Dalam pengendalian modul voice 4321 dilakukan konfigurasi terhadap modul aplikasi dengan membuat direktori untuk penyimpanan file driver modul voice 4321. Pembuatan direktori menggunakan perintah "mkdir-p /opt/ED255_NFS_ROOT/work/Robot_ARM/Voice". File driver dan program aplikasi modul voice 4321 akan dicrosscompiling menjadi format file "voice.o" dengan menggunakan perintah "make". File driver dan program aplikasi dengan format "voice.o" disalin ke ED-255EK dengan menggunakan perintah "insmod voice.o". Pada program aplikasi modul voice 4321 dieksekusi dengan menekan tombol Reset, tombol Recog, dan tombol Traning secara bergantian. Saat led indikator menyala maka modul akan merekam suara yang diberikan. Lakukan langkah tersebut sampai 3 kali dengan rekaman suara yang berbeda. Maka data hasil perekaman modul voice 4321 ditunjukkan pada Tabel 2.

TABEL 2

DATA HASIL MODUL VOICE 4321

\begin{tabular}{|c|c|c|c|}
\hline No & Input $(\boldsymbol{R e c})$ & Output () & Keteranan \\
\hline 1 & Cek & Cek & Jelas terdengar \\
\hline 2 & O & O & Jelas terdengar \\
\hline 3 & B & B & Kurang jelas terdengar \\
\hline
\end{tabular}

\section{KESIMPULAN}

Adapun simpulan yang diperoleh dari penelitian ini adalah sebagai berikut:

A. ED-255EK Embedded Education Platfrom dapat digunakan sebagai modul praktikum embedded system berbasis linux.

B. Pengendalian modul robot ARM 1923 memerlukan file driver dan file program yang di-compling dengan menggunakan Make file. Sedangkan modul voice hanya memerlukan file driver yang di-compling dengan menggunakan Make file.

C. Bedasarkan penelitian yang dilakukan, modul robot ARM dan modul voice dapat dijadikan modul praktikum embedded system berbasis linux karena mampu memberikan data keluaran yang sesuai dengan data masukan yang diberikan.

\section{REFERENSI}

[1] Jatmiko, Wisnu. 2015. Real Time Operating System (RTOS) Teori dan Aplikasi. Depok : Universitas Indonesia.

[2] Tukadi; Hakimah, Maftahantul. 2017. Pembelajaran Embedded System Berbasis Arduino Mega 2560 dan MIT App Inventor. Jurnal Ilmiah Mahasiswa Universitas Dr Utomo. ISSN 2502-3470

[3] Fauziah, Mila; Fatkhur Roman; Beauty Anggraheny Ikawanti. 2016. Penerapan Modul Arduino Untuk Sistem Pembelajaran Prinsip Kerja Didplay LCD Touch Screen 3,2 Inch Pada aplikasi Data Curved Ploting. Jurnal Ilmiah Mahasiswa Universitas Politeknik Negeri Malang. Vol.14 No.02

[4] Budijnato Arief; Shoim Achmad. 2015. Prototipe Modul Pembelajaran Embedded System Berbasis Arduino. Seminar Nasional Sain dan Teknologi terapna III 2015 Institut Teknologi Adhi Tama Surabaya. ISBN 978-602-98569-1-0.

[5] Barkhat, 2013. Pengertian, Sejarah, Kelebihan dan Kekurangan Linux Fedora.

http://barkahtroox.blogspot.co.id/2013/02/pengertian-linux-sejarah linux.html

[6] Morio, 2016. Kontrol Robot ARM Dengan Arduino. https://inkubatorteknologi.com/kontrol-robot-arm-dengan-arduino/ 